\title{
Contribution Concerning the Behaviour Knowledge before Natural Swarming in Honeybees (Apis mellifera carpathica, Linnaeus)
}

\author{
Ilie CORNOIU ${ }^{1}$, Ionel TOADER ${ }^{1}$, Ovidiu MAGHIAR ${ }^{2}$, Mirela CADAR ${ }^{1 *}$ \\ ${ }^{1}$ Faculty of Animal Science and Biotechnologies, University of Agricultural and Veterinary Medicine Cluj- \\ Napoca, 3-5 Mănăștur Street, 400372 Cluj-Napoca, Romania \\ ${ }^{2}$ Private beekeeper, Jucu, Cluj County, Romania \\ *corresponding author: mirucadar@yahoo.com
}

Bulletin UASVM Animal Science and Biotechnologies 77(1)/ 2020

Print ISSN 1843-5262; Electronic ISSN 1843-536X

DOI:10.15835/buasvmcn-asb: 0014.19

\begin{abstract}
In this study we followed the way in which evolves the behaviour of some honeybee families (Apis mellifera carpathica, Linnaeus), maintained in vertical beehives (modified Dadant type), in conditions of stationary bee keeping, having in view the natural queen cell's build rhythm after the second acacia tree harvest (Robinia pseudoacacia L.) in Jucu area of Cluj County. There were taken into observation 20 biological units with queen bees of different ages. It was monitored the development rhythm of natural queen cells, which are in attendance by the working bees, and to put into evidence the swarming instinct strength, so in bee keeping practice to be known and to be avoided the natural swarming. The determination of occupied surfaces with covered brood and larval was effected with the Netz framework. The aim of our study was to understand how the swarming in honeybees occurs. By detailed observation, we want to describe and to explain the behaviour of honeybees before the swarming process. The obtained results are quantified in absolute values and expressed graphically in relative values, but in the next three apicultural years $(2020,2021$ and 2022), the experiment will be repeated for a variance analysis, which will provide a statistical assurance. We hope that these data will give contribution for the apicultural practice, keeping attention on queen bees' importance during active season and on careful supervision on development rhythm of the honeybee units during the natural swarming.
\end{abstract}

Keywords: Apis mellifera carpathica L, brood, queen cells, natural swarming, biological unit

\section{Introduction}

During one-year seasons, the honeybee family undergoes different biological development stages. After winter outcome and flowering of the first plants from spontaneous flora, the queen bee begins to lay eggs on greater surfaces in the combs' cells, so after acacia tree harvest end the family reaches a culmination of numerical development associated to a nest blockage with nectar and pollen. Such status settlement determines honeybees to build queen cells on lateral sides of the nest honeycombs, and the entire family will get into so named "swarming cold" (Ruttner, 1980).
The biological unit will multiply alone if in few days there do not intervene for its artificial partition. Thus, a great part of honeybees, together with the queen bee, will abandon the hive, and in the nest will remain the rest of honeybees, which takes care of queen cells from which will hatch the young queen bees (Getz et al., 1982).

The natural uncontrolled swarming of honeybee families is much discussed in the beekeeping practice and the specialty literature, and can generate important productive damages in the apiary (Bistriceanu, 2011). 
Probably, the most detailed description of swarming process was done by Huber in 1792 (cited by Delia Allen, 1955), but without any account data it is difficult to understand the behaviour of honeybees before swarming. Many theories tried to explain the causes which lead to honeybee family division, and through certain experiments were tested some factors which could play this role, such as: increasing the colony size, changing the age distribution of working bees and nest crowding with brood (Getz et al., 1982; Simpson, 1973; Winston and Taylor, 1980).

Generally, the swarming represents a natural multiplication instinct of honeybee families, which reach a high development point as concerns the bee number and energetic proteic food. The honeybee families suffer a biological disequilibrium, because the working bees (regularly nurse bees) are in great number and they are not capable to feed and keep care of the brood in larval stage (Cîrnu and Roman, 1986). In such situations, the majority of cells from surfaces of the built combs are full of nectar and pollen, so the queen bees have not enough space for laying eggs (Ruttner, 1980). Because of this, the queen bees will retreat to periphery of the built combs and will lay eggs in the marginal cells. In few days, the marginal cells will be rapidly built up by the working bees, and will been transformed in the swarming queen cells, similar to acorns of different sizes (Borst, 2011; Hristea, 1976; Bistriceanu, 2011).

In conditions of our country, this important moment of honeybees' life begins near to acacia tree harvest end (Robinia pseudoacacia L.) until the second decade of June, but differently depending on each biological unit strength, and also on the situation of natural harvest from an apicultural zone to another one (Siceanu and Căuia, 2009).

Having in view the fact, that natural multiplication (swarming) produces a new biological unit, but without fertilized queen bee and in a bio-functional disequilibrium of the new honeybee family, we consider that it is necessary to know the behaviour of honeybees during precursory swarming period. Why? Because in this way we can prevent the swarming phenomenon and in the apiary will be limited the losses.

\section{Materials and methods}

The study was effected during May 25 and June 15, 2019, after the second acacia tree harvest
(Robinia pseudoacacia L.), on a number of 20 honeybee families (Apis mellifera carpathica, Linnaeus) maintained in stationary breeding system in Jucu area of Cluj County.

The biological material was kept in vertical beehives, on 12 frames (modified Dadant type) with external sizes of $435 \times 300 \mathrm{~mm}$ and internal ones of $415 \times 270 \mathrm{~mm}$, provided with two store places, each of 10 frames with $1 / 2$ of size of the nest frames.

The research were effected in the bioapicultural zone situated in the South side of Jucu commune, at $23 \mathrm{~km}$ distance from Cluj city, having 30 ha of forest, 15 ha of acacia plantation for the second harvest, 150 ha of fruit trees and about 1,500 ha of pastures.

During April was effected the stimulating feeding based on sugar syrup $1 \mathrm{~kg}$ of sugar in $2 \mathrm{~L}$ of water), $200 \mathrm{~mL} /$ family at each two days, in feeding places on the nest edge. Gradually, depending on each family development rhythm there were being introduced 2 or 3 frames with artificial combs for build. This action was done also to stimulate rapidly the development of biological units for a better capitalization of natural meliferous sources from the studied zone, especially of the second harvest of the acacia tree.

During the spring season of 2019, the weather conditions were favourable, with minimal temperatures of 9-180C and maximal ones of 19330C, being greater with 50C respectively with $100 \mathrm{C}$ given to those ones registered in the same period of 2018 (Table 1).

In these conditions, the biological units benefited of daily flights for abundant natural harvest, represented by spontaneous flora of the pasture and forest, and of the fruit trees.

After the second acacia tree harvest, the average potency of the biological units gets to 4.5 $\mathrm{kg}$ of bees (about 40,500 individuals in the stages of nurse and worker bees).

For a better observation, the queen bees were marked with white colour (3 years old), with yellow colour ( 2 years old) and with red colour (1-year-old). The age data of the queen bees were been registered in the beehive accountancy.

During our researches, the biological units were been daily monitored from 9.00 to 12.00 hours a.m., we determined the surfaces with covered and uncovered brood using the Netz framework. Practically, the Netz frame is a 
Table 1.Temperature evolution in the Cluj monitored area during May and June 2019 (https://www.accuweather.com/ro/ro/cluj-napoca/287713/may-weather/287713?year=2019)

\begin{tabular}{|c|c|c|c|c|}
\hline May 21, 2019 & May 22, 2019 & May 23, 2019 & May 24, 2019 & May 25, 2019 \\
\hline \multicolumn{5}{|c|}{ Effective Temperature Effective Temperature Effective Temperature Effective Temperature Effective Temperature } \\
\hline $19^{0} / 9^{0}$ & $21^{0} / 7^{0}$ & $20^{0} / 12^{0}$ & $19^{0} / 11^{0}$ & $21^{0} / 10^{0}$ \\
\hline Historical averages & Historical averages & Historical averages & Historical averages & Historical averages \\
\hline $21^{0} / 9^{0}$ & $21^{0} / 9^{0}$ & $21^{0} / 9^{0}$ & $21^{0} / 9^{0}$ & $21^{0} / 10^{0}$ \\
\hline May 26, 2019 & May 27, 2019 & May 28, 2019 & May 29, 2019 & May 30, 2019 \\
\hline \multicolumn{5}{|c|}{ Effective Temperature Effective Temperature Effective Temperature Effective Temperature Effective Temperature } \\
\hline $25^{0} / 10^{0}$ & $24^{0} / 11^{0}$ & $27^{0} / 14^{0}$ & $24^{0} / 13^{0}$ & $22^{0} / 13^{0}$ \\
\hline Historical averages & Historical averages & Historical averages & Historical averages & Historical averages \\
\hline $21^{0} / 10^{0}$ & $22^{0} / 10^{0}$ & $22^{0} / 10^{0}$ & $22^{0} / 10^{0}$ & $22^{0} / 10^{0}$ \\
\hline May 31, 2019 & June 01, 2019 & June 02,2019 & June 03, 2019 & June 04, 2019 \\
\hline \multicolumn{5}{|c|}{ Effective Temperature Effective Temperature Effective Temperature Effective Temperature Effective Temperature } \\
\hline $23^{0} / 12^{0}$ & $21^{0} / 13^{0}$ & $26^{0} / 12^{0}$ & $22^{0} / 13^{0}$ & $26^{0} / 14^{0}$ \\
\hline Historical averages & Historical averages & Historical averages & Historical averages & Historical averages \\
\hline $22^{0} / 10^{0}$ & $22^{0} / 10^{0}$ & $22^{0} / 10^{0}$ & $22^{0} / 10^{0}$ & $22^{0} / 11^{0}$ \\
\hline June 05, 2019 & June 06, 2019 & June 07, 2019 & June 08, 2019 & June 09, 2019 \\
\hline \multicolumn{5}{|c|}{ Effective Temperature Effective Temperature Effective Temperature Effective Temperature Effective Temperature } \\
\hline $23^{0} / 14^{0}$ & $24^{0} / 14^{0}$ & $26^{0} / 14^{0}$ & $29^{0} / 14^{0}$ & $30^{0} / 17^{0}$ \\
\hline Historical averages & Historical averages & Historical averages & Historical averages & Historical averages \\
\hline $22^{0} / 11^{0}$ & $22^{0} / 11^{0}$ & $23^{0} / 11^{0}$ & $23^{0} / 11^{0}$ & $23^{0} / 11^{0}$ \\
\hline June 10, 2019 & June 11, 2019 & June 12, 2019 & June 13, 2019 & June 14, 2019 \\
\hline \multicolumn{5}{|c|}{ Effective Temperature Effective Temperature Effective Temperature Effective Temperature Effective Temperature } \\
\hline $29^{0} / 15^{0}$ & $28^{0} / 14^{0}$ & $29^{0} / 15^{0}$ & $31^{0} / 15^{0}$ & $33^{0} / 16^{0}$ \\
\hline Historical averages & Historical averages & Historical averages & Historical averages & Historical averages \\
\hline $23^{0} / 11^{0}$ & $23^{0} / 11^{0}$ & $23^{0} / 12^{0}$ & $23^{0} / 12^{0}$ & $23^{0} / 12^{0}$ \\
\hline June 15, 2019 & June 16, 2019 & June 17, 2019 & June 18, 2019 & June 19, 2019 \\
\hline \multicolumn{5}{|c|}{ Effective Temperature Effective Temperature Effective Temperature Effective Temperature Effective Temperature } \\
\hline $32^{0} / 18^{0}$ & $32^{0} / 18^{0}$ & $29^{0} / 17^{0}$ & $29^{0} / 15^{0}$ & $30^{0} / 16^{0}$ \\
\hline Historical averages & Historical averages & Historical averages & Historical averages & Historical averages \\
\hline $23^{0} / 12^{0}$ & $24^{0} / 12^{0}$ & $24^{0} / 12^{0}$ & $24^{0} / 12^{0}$ & $24^{0} / 12^{0}$ \\
\hline
\end{tabular}

rectangular framework, made of soft wood, with the dimensions of a nest frame $(435 \times 300$ $\mathrm{mm} / 415 \times 270 \mathrm{~mm}$ ), divided with nylon fibre in squares of $5 \times 5 \mathrm{~cm}$, each square having a surface of $25 \mathrm{~cm} 2$. By overlapping the Netz frame on each nest frames we established the number of covered and larval brood per each square.

The aim of our study was to understand how swarming in honeybees occurs. By detailed observation, we want to describe and to explain the behaviour of honeybees before the swarming process.

At an early stage of our researches, the obtained results were quantified in absolute values and expressed graphically in relative values, but in the next three apicultural years (2020, 2021 and 2022), the experiment will be continued and repeated for a variance analysis, which will provide a statistical assurance.

\section{Results and discussions}

From the data presented in Figure 1 comes out that in experiment start (corresponding for the end of second acacia tree harvest) the average surfaces with covered brood have occupied $58.7 \%$ in the honeybee families with queen bees of 2 years old. The honeybee families with queen bee of 3 years old had average surfaces with covered 


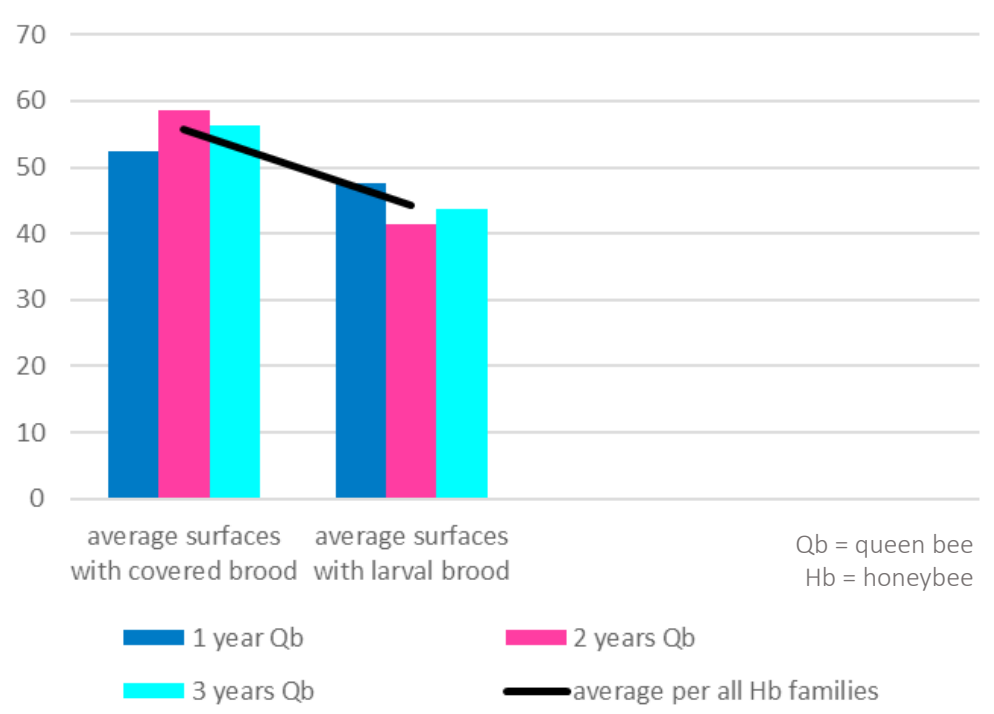

Figure 1. The average surfaces with covered and larval brood in the research beginning

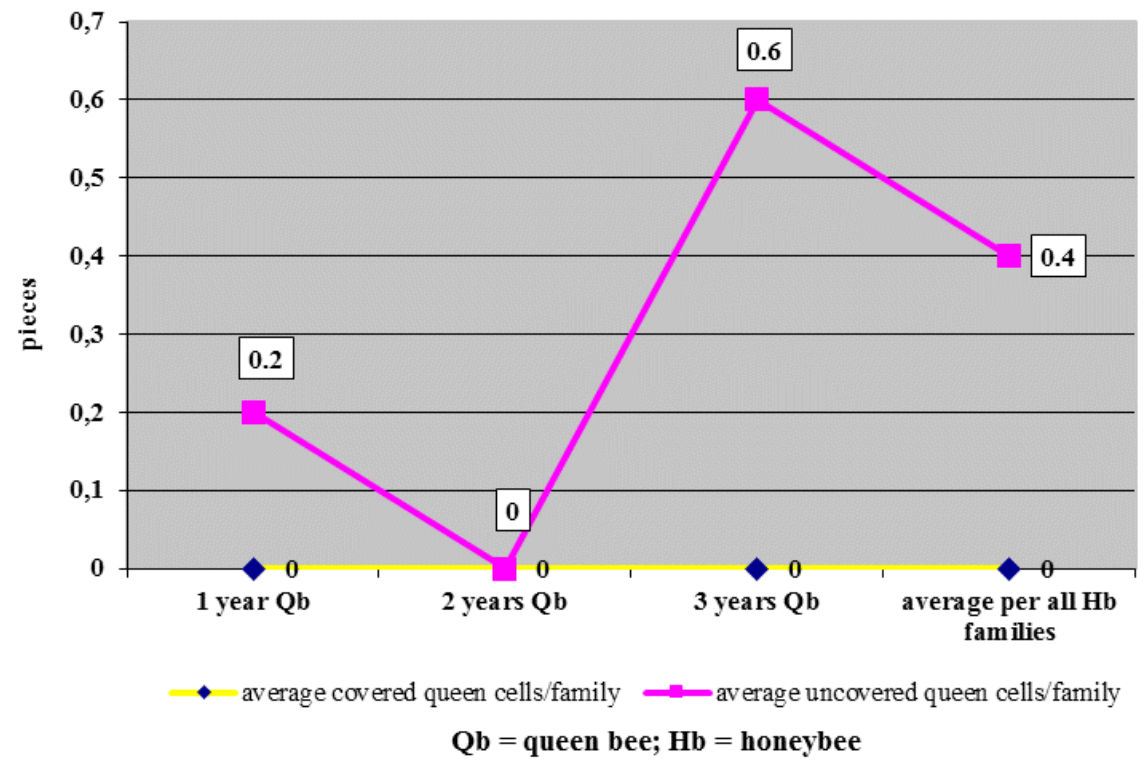

Figure 2. The average number of the queen cells per honeybee family in the research beginning

brood of $56.3 \%$, and the honeybee families with queen bees of 1-year-old had average surfaces of $52.4 \%$. The average value per all families was of $55.8 \%$.

Great differences (6.3\%) were been registered between honeybee families with 1-year-old queen bees and those of 2 years old. We consider that the differences are due to the age of queen bees, which means that 2 years old queen bees are more prolific stimulating the bee instinct for harvesting and all the activities carried out in the hive.

As concern the average surfaces occupied by larval brood of different age, from the same chart data comes out that these values varied between $47.6 \%$, in the honeybee families with queen bees of 1 year old, and $43.7 \%$ in case of those ones with queen bees of 3 years old, with an average value per all families of $44.2 \%$.

As concern the average number of queen cells identified in the nests of honeybee families, comes out that those covered were absent, and those uncovered were present only in the families with queen bees of 1 year and 3 years old, with an average value per all families of 0.4 pieces (Figure 2). 


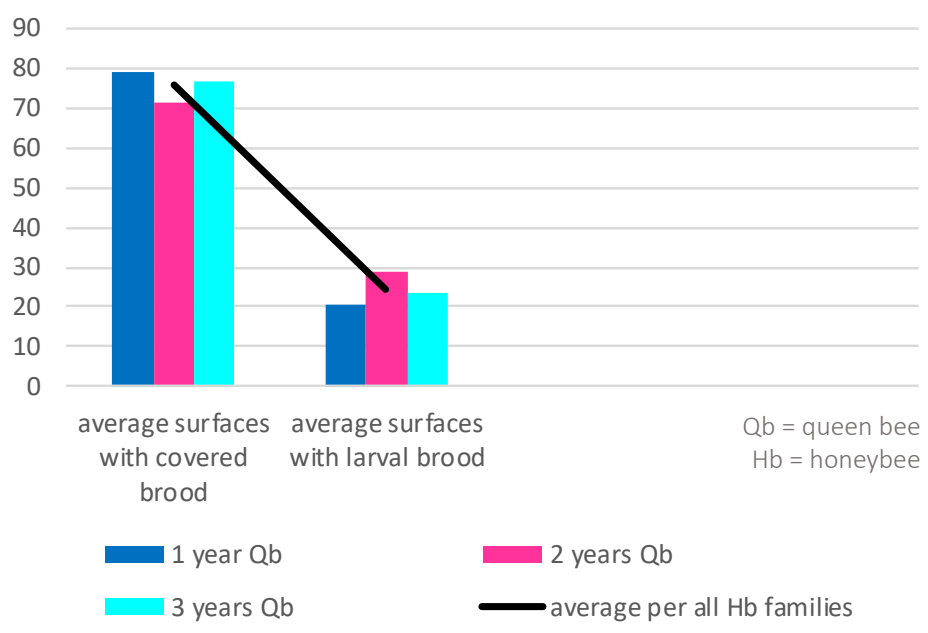

Figure 3. The average surfaces with covered and larval brood after the first week

In her researches, Delia Allen (1955) observed in the preliminary period of swarming (end of May, in North of Scotland College of Agriculture, UK) only a single queen cell formation, in a small honey bee family (about 4,500 honeybees) with a 1 -year-old queen bee, maintained in a hive with three vertical frames of brood (British Standard Brood frames).

Practically, after the end of the second acacia tree harvest, we appreciate that the honeybee families kept a balanced rhythm of biological functionality, but the presence of uncovered queen cells represented the first signal of swarming instinct settlement.

After the first week of researches, we followed up the surfaces with covered and larval brood, but also the evolution of the queen cells taken for breeding on each frame by each honeybee family. The data presented in Figure 3 reveals that the average surfaces with covered brood (from the nest frames) occupied $79.2 \%$ in honeybee families with queen bees of 1 year old. The honeybee families with queen bees of 3 years old registered average surfaces of $76.5 \%$, and only $71.7 \%$ in the honeybee families with queen bees of 2 years old. The average value per all families was of $75.8 \%$ and great differences $(7.5 \%)$ were been registered between the families with 1-yearold and 2 years old queen bees. We consider that these differences are due to favourable season conditions, abundance of food, which stimulated the queen bees to be so prolific.

Concerning the average surfaces occupied by the larval brood of different ages, it comes out that these surfaces varied between $28.9 \%$ in case of families with queen bees of 2 years old and $20.8 \%$ in case of those with queen bees of 1-year-old, with an average value per all families of $24.4 \%$. We consider that the queen bees of 2 years old are more experimented than the queen bees of 1-yearold, so they continuously stimulate the honeybees' activities.

Getz et al. (1982) worked on two kindred honeybee colonies (by queen bee), which benefited by natural swarming. They observed significant differences as concerns the normal brood obtained from both colonies. The differences were between 15 and 26\% during seven days (average values of $15 \%$ and $41 \%$ for the first colony; average values of $26 \%$ and $41 \%$ for the second colony).

Related to the average number of covered queen cells identified in the nest of honeybee families, we observed that it varied between 42.8 pieces (in honeybee families with queen bees of 2 years old) and 39.5 pieces (in honeybee families with queen bees of 1 year old), with an average value per all families of 40.9 pieces (Figure 4). We consider that the differences are due to the honeybees' experience depending on queen bee age. As concerns the honeybee families with queen bees of 3 years old, we observed a decreasing for laying fertilized eggs, due to the bee aging.

The number of uncovered queen cells, but in covering process, was different with relatively close values in the studied honeybee families. Thus, from the data presented in Figure 4, their number varied between 6.2 pieces (in families with queen bees of 1-year-old) and 7.5 pieces (in 


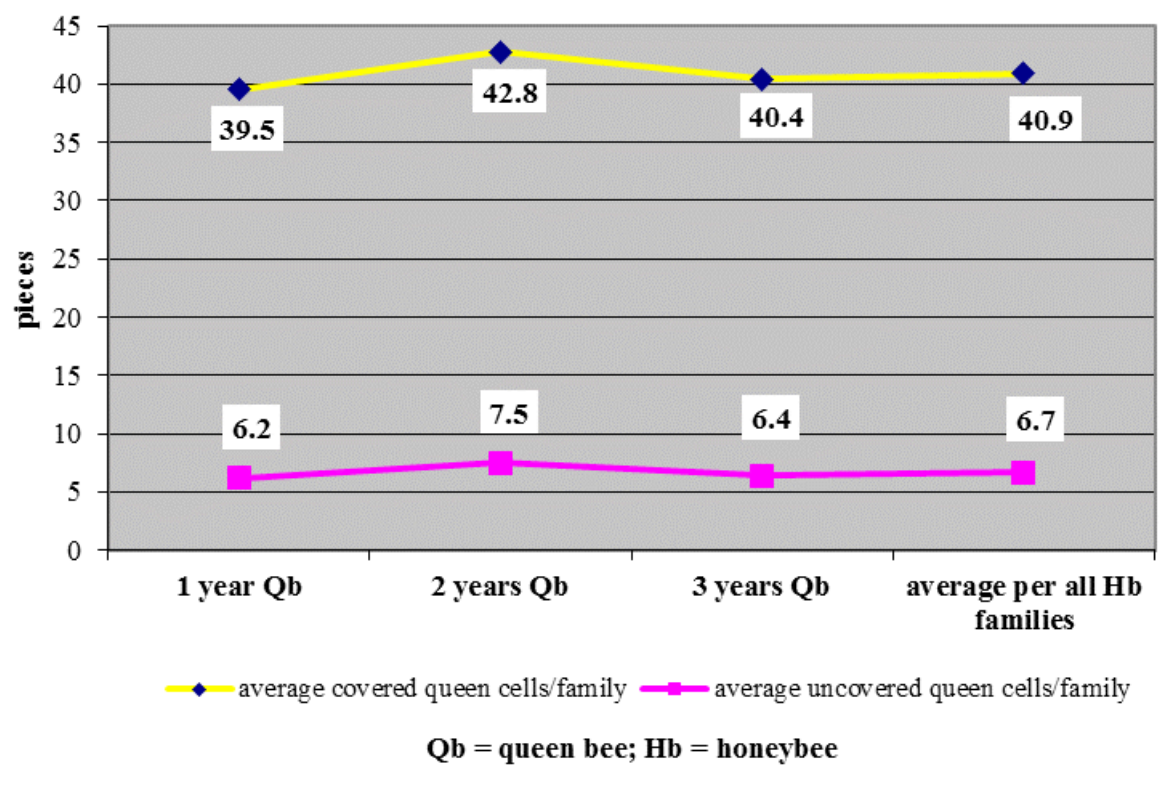

Figure 4. Tthe average number of the queen cells per honeybee family after the first week

families with queen bees of 2 years old), with an average value per all families of 6.7 pieces.

In her study, Delia Allen (1955) observed that were build more 16-queen cells, with a frequency of 1-2 queen cells per day during two weeks (until July 14). From these queen cells, only seven were covered and from these only four hatched young queen bees. In this case, the long time for building of queen cells could be explain by the studied geographic zone and its climate.

Making comparison after the first week from the study beginning and after the main harvest ending on acacia tree (Robinia pseudoacacia L.), we appreciate that irrespective of queen bees ages, all the honeybee families rapidly came in "swarming cold", and the average surfaces occupied by covered brood were more widespread $(73.73 \%)$ given to those ones occupied by larval brood (26.27\%).

In the same connection, as concerns the situation of queen cells covered after the first week, these were in a greater proportion (84.3\%) given to those uncovered ones (15.7\%).

Practically, the rapid changes of physiological structure determined by covered and larval brood stages, corroborated with laying decrease of the queen bees, have influenced the harvesting activity of working bees from each family, these ones crowding together and lazing in long "beard" under flying plank. In that stage, the biological units get to natural multiplication, the swarming being practically infallible. We recommend the intersession of the beekeeper, which became obligatory to prevent the losses in the apiary.

\section{Conclusion}

Pursuant to our researches concerning the behaviour before natural swarm in honeybees (Apis mellifera carpathica, Linnaeus), there can be formulated subsequent conclusions and recommendations:

- in Jucu area from Cluj County, the apicultural season of 2019 was swarming because of springtime, which allowed the early development of honeybee families;

- after acacia tree (Robinia pseudoacacia L.) main harvest ending, beside its intense capitalization, the honeybee families directed their specific activities to natural multiplication (swarming) by taking in care a greater number of queen cells and blocking the nest with energetic proteic food and covered brood;

- even the age of queen bees do not emphasized relative great differences among honeybee families as concern the evolution of behaviour before natural swarming, we appreciate that an important role could be assigned to bio-apicultural zones, which provided an appropriated development of biological units;

- as a recommendation, we suggest for beekeepers, especially the beginner ones, that after acacia tree harvest, must be supervised more often and carefully the honeybee families, and by 
votive techniques to be avoided their natural multiplication.

\section{References}

1. Allen D (1955). The behaviour of honeybees preparing to swarm. The Brit. J. anim. Behav. IV, 1, 14-22.

2. Bistriceanu GhE (2011). Apicultura, vol I, Editura Eledra, București.

3. Borst Peter Loring (2011). The perfect swarm. Part one. Americal Bee Journal 2011:331-333.

4. Căuia E, Siceanu A, Cebotari V (2009). Câteva aspecte privind selecția și creșterea mătcilor pentru îmbunătățirea productivității stupinelor, Rev. România Apicolă, 6, 4-8. ACA România.

5. Cîrnu L, Roman G (1986). Din viața albinelor, Editura Ceres, București.

6. Getz WM, Bruckner D, Parisian TR (1982). Kin structure and the swarming behavior of the honey bee Apis mellifera. Behav. Ecol. Sociobiol. @Springer-Verlag (1982) 10:265-270

7. Hristea CL (1976). Stupăritul nou, A.C.A. România.

8. Ruttner F (1980). Creșterea mătcilor-baze biologice și indicații tehnice, (C)Springer Verlag, Berlin.

9. Siceanu A, Căuia E (2009). Evoluția albinei melifere (Apis mellifera L.) și necesitatea păstrării diversității raselor de albine, Rev. România Apicolă, 9, 12-17, ACA România.

10. Simpson J (1973). The influence of hive space restriction on the tendency of honeybee colonies to rear queens. J. Apic. Res. 12:183-186.

11. Winston ML, Taylor OR (1980). Factors precedind queen rearing in the Africanized honeybee (Apis mellifera) in South America. Insectes Soc. 27: 289-304.

12. https://www.accuweather.com/ro/ro/cluj-napoca/ 287713/may-weather/287713?year=2019 